Original Research Paper

\title{
Analysis of Cyanide (CN) in Seagrass as a Bioindicator in Sekotong West Lombok
}

\author{
Alwani', Agil Al Idrus', M. Yamin ${ }^{1 *}$ \\ ${ }^{1}$ Biology Education Program Study, FKIP, University of Mataram, Indonesia
}

\author{
Article History \\ Received : December 05 ${ }^{\text {th }}, 2021$ \\ Revised : December $15^{\text {th }}, 2021$ \\ Accepted : December $25^{\text {th }}, 2021$ \\ Published : January $10^{\text {th }}, 2022$ \\ *Corresponding Author: \\ M. Yamin, \\ Biology Education Program Study, \\ FKIP, University of Mataram, \\ Indonesia \\ Email: \\ Muhammadyamin.fkip@gmail.com
}

\begin{abstract}
Seagrass is one of the aquatic plants that can be used as a bioindicator in the waters. This research aims to determine the morphological structure of seagrass as bioindicators and the amount of cyanide content in seagrass plants in the waters of Sekotong, West Lombok. This research was conducted in July - August 2021 at Pewaringan Beach, Sekotong, West Lombok. Determination of the sample point is done by purposive sampling. Data were collected using line transect method simple random sampling at three points. Data analysis was carried out on seagrass plants with complete roots, stems, and leaves using a spectrophotometer at BLKPK NTB Province. The results showed that the characteristics of seagrass in the three research locations had a slightly muddy sandy substrate and slightly sandy muddy, an average leaf length of $21.5 \mathrm{~cm}$, an average leaf width of $1.10 \mathrm{~cm}$, an average stem length of $9.4 \mathrm{~cm}$, diameter the average stem is $0.74 \mathrm{~cm}$, the average root length is 7.29 and the average root diameter is $0.25 \mathrm{~cm}$. The ANOVA test showed that the significant value was $<0.05$, so there was a significant difference in the morphology of the seagrass. The cyanide content in the waters of Pewaringan Beach was found to be on average $12,341 \mathrm{mg} / \mathrm{kg}$ or $0.495 \mathrm{mg} / \mathrm{L}$. According to the Ministry of Health of the Republic of Indonesia No. 57 of 2016 the standard cyanide content in waters is $0.5 \mathrm{mg} / \mathrm{L}$. So that the cyanide content in the waters of Pewaringan Beach is still within safe limits.
\end{abstract}

Keywords: Bioindicator, Cyanide, Sekotong

\section{Pendahuluan}

Lamun (Seagrass) merupakan tumbuhan berbunga yang termasuk dalam kelas Angiospermae. Lamun biasa dikenal dengan ilalang laut yang hidup dan menyesuaikan diri sepenuhnya di dalam air laut (Boneka, 2013). Lamun merupakan tumbuhan berbunga yang hidup di perairan laut serta tumbuh subur terutama di daerah pasang surut dan perairan pantai dengan substrat berupa lumpur, pasir, kerikil dan patahan karang mati dengan kedalaman dari 8-15 meter bahkan bisa mencapai 40 meter (Noviarini dan Ermavitalini, 2015). Lombok merupakan salah satu pulau di Indonesia yang memiliki wilayah perairan dan ekosistem lamun yang baik. Syukur (2015) menyatakan lamun di perairan pesisir Pulau Lombok ditemukan sebanyak 9 spesies dari 12 spesies lamun yang ada di peraian Indonesia. Distribusi 9 spesies lamun di perairan pesisir Lombok Timur ditemukan dibagian selatan yaitu di Teluk Jukung (Tanjung Luar) serta ditemukan sebanyak 8 spesies lamun di pantai Kute dan Gerupuk. Selanjutnya pada pantai ujung Kecamatan Jerowaru Lombok Timur ditemukan ada 6 (enam) jenis lamun.

Luasnya penyebaran lamun di Lombok salah satunya di perairan Sekotong, Kecamatan Sekotong, Lombok Barat. Susila et al. (2018) menyatakan tutupan lamun di pantai Pewaringan Sekotong mencapai $50,15 \%$ yang memberikan pengaruh terhadap kelimpahan echinodermata karena lamun merupakan habitat dari fauna echinodermata. Ramdhoni et al. (2017) menyatakan kondisi substrak di Pantai Pewaringan Sekotong merupakan habitat lamun dengan kondisi substrat dominan berlumpur dengan tingkat pencahayaan yang cukup bagi pertumbuhan lamun. Kondisi yang berlumpur ini diakibatkan oleh tanah perbukitan yang tidak stabil serta berdekatan dengan bibir pantai sehingga saat musim penghujan kondisi perairan akan cenderung berlumpur. Substrat berlumpur menyebabkan hanya beberapa spesies lamun 
tertentu yang ditemukan seperti Halodule pinipofolia.

Lamun memiliki fungsi yang penting di lingkungan laut diantaranya sebagai habitat hidup biota laut, produktivitas primer, mengatur tingkat trofik serta regulasi gas untuk keseimbangan gas $\mathrm{CO}_{2}$ dan $\mathrm{O}_{2}$ di atmosfir melalui mekanisme fotosintesis (Syukur et al., 2017). Lamun dapat menjadi bioindikator lingkungan karena lamun dapat menyerap dan mengakumulasikan logam berat di dalam organ tubuhnya. Jika kandungan logam berat diperairan meningkat maka akan mengancam ekosistem laut serta biota yang hidup didalamnya (Zamani et al., 2018). Sekotong merupakan salah satu daerah di Nusa Tenggara Barat dengan potensi tambangan emas yang besar, sehingga memiliki potensi terjadinya pencemaran lingkungan laut akibat aktivitas penambang emas liar. Astiti dan Sugianti (2014) menyatakan jenis penggelondongan menggunakan tong merupakan tehnik akhir untuk mendapatkan biji emas dengan menggunakan sianida $(\mathrm{CN})$ yang memiliki tingkat keberhasilan 99\%. Sianida selain sebagai zat kimia aktif juga efisien digunakan untuk mengekstrak biji emas. Sehingga banyak penambang emas menggunakan sianida untuk mengekstrak biji emas. Krisnayanti et al. (2012) di lokasi PESK di Kecamatan Sekotong, Kabupaten Lombok Barat menunjukkan bahwa limbah penambangan proses amalgamasi rata-rata masih mengandung $\mathrm{Hg} 3.002 \mathrm{mg} / \mathrm{kg}$, sedangkan limbah hasil sianidasi masih mengandung $1.628 \mathrm{mg} / \mathrm{kg}$. Penelitian Astiti dan Sugianti (2014) menyatakan rata-rata lokasi penelitian di Lombok Barat mengandung kadar sianida pada tanah, air dan beras secara berturut-turut $22,2 \%$; $66,7 \%$; dan 40,7\% yang menunjukan bahwa lokasi pencemaran merkuri dan sianida oleh penambang emas sangat luas.

Tingginya kandungan logam berat dilingkungan yang tercecer dikhawatirkan akan mengkontaminasi perairan dan kesehatan masyarakat setempat sehingga perlunya dilakukan penelitian tentang kandungan sianida untuk mengetahui dan memberikan edukasi kepada masyarakat tentang bahaya sianida bagi kesehatan dengan memanfaatkan kekayaan sumber daya alam berupa padang lamun diperairan Sekotong. Diharapkan penelitian ini dapat bermanfaat untuk menambah wawasan dan informasi terkait kandungan sianida pada tanaman lamun.

\section{Bahan dan Metode}

\section{Alat dan Bahan}

Alat yang digunakan dalam penelitian ini adalah oven, neraca analitik, krus atau cawan porselin, tanur listrik $550^{\circ} \mathrm{C}$, refraktometer, salinometer, ember, penggaris, kantong plastik bening, kertas saring, parfilm, pipet tetes, gelas ukur, labu volumetrik, corong, masker, kaos tangan karet, kuadran $1 \mathrm{x} 1 \mathrm{~m}$, dan spektrofotometer panjang gelombang $612 \mathrm{~nm}$. Bahan yang digunakan yaitu sampel tanaman lamun, aquades, dan reagen sianida.

\section{Waktu dan Tempat}

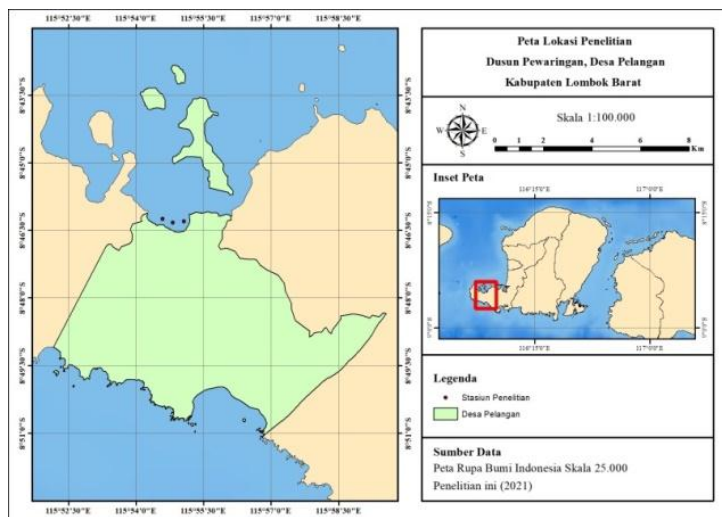

Gambar 1. Peta Lokasi Penelitian

Penelitian ini dilakukan pada bulan Juni Agustus 2021. Lokasi penelitian di Pantai Pewaringan, perairan Sekotong, Kabupaten Lombok Barat. Pengambilan sampel dilakukan pada tiga titik. Stasiun 1 merupakan lokasi terdekat dengan tambak nelayan setempat, dengan titik koordinat (S $8^{0} 466^{\prime} 30^{\circ}-\mathrm{E}$ $115^{\circ} 54^{\prime} 0^{\circ}$ ), Stasiun 2 merupakan lokasi yang berada ditengah-tengah ekosistem lamun, dengan titik koordinat (S $8^{0} 46^{\prime} 01^{0}$ - E $115^{\circ} 51^{\prime} 10^{\circ}$ ), dan stasiun 3 merupakan lokasi yang berdekatan dengan pemukiman warga dengan titik koordinat (S $8^{0} 48^{\prime} 11^{0}$ E1 $15^{\circ} 56^{\prime} 14^{\circ}$ ). Setiap stasiun berjarak 50 meter dari bibir pantai dengan jarak antar stasiun masing - masing 100 meter.

Tehnik penentuan stasiun penelitian menggunakan tehnik Purposive sampling. Pengambilan sampel dilakukan dengan metode transek garis secara acak pada petak kuadrat $1 \mathrm{x} 1$ meter pada saat air laut surut di tiga titik ( Christon et al., 2012). Uji kandungan sianida dilakukan di Balai Labolatorium Kesehatan Pengujian dan Kalibrasi (BLKPK) Provinsi NTB. 


\section{Metode Penelitian}

Variabel yang diteliti pada penelitian ini yaitu kadar sianida $(\mathrm{CN})$ pada tanaman lamun yang ada di wilayah perairan Sekotong khususnya di Pantai Pewaringan. Tanaman lamun diambil dalam bentuk tanaman utuh menggunakan alat pemotong berupa gunting atau secara manual pada tanaman yang memiliki akar, batang, dan daun lengkap. Selanjutnya diukur tinggi, lebar, dan diameter pada daun, batang, dan akar lamun. Terakhir sampel akan dimasukan kedalam kantong plastik bening ukuran $1 \mathrm{Kg}$ dan dibawa ke BLKPK Provinsi NTB.

Preparasi sampel dimulai dengan mencuci tanaman lamun hingga tidak ada sampah dan lumpur yang menempel pada tanaman. Selanjutnya tanaman lamun di dijemur selama 1 hari lalu dikeringkan didalam oven pada suhu $105^{\circ} \mathrm{C}$ selama 2 jam untuk menghilangkan kadar airnya. Kemudian sampel diabukan dalam tanur listrik dengan suhu $550^{\circ} \mathrm{C}$ selama 2 jam hingga sampel menjadi abu (Yuzhira, 2010).

Uji kandungan sianida dimulai dengan sampel abu lamun ditimbang sebanyak 2 gr lalu dilarutkan menggunakan aquades $50 \mathrm{~mL}$ dan disaring menggunakan kertas saring sebanyak tiga kali penyaringan. Selanjutnya larutan diambil sebanyak $10 \mathrm{~mL}$ pada masing-masing sampel untuk dihomogenkan dengan reagen sianida. Reagen sianida yang digunakan yaitu bubuk reagen sianida. Setelah semua reagen dicampurkan dengan masing-masing sampel selanjutnya ditutup menggunakan parfilm dan diinkubasi selama 30 menit. Terakhir sampel dimasukan kedalam spektrofotometer dengan panjang gelombang $612 \mathrm{~nm}$ untuk diukur kandungan sianidanya (Tim BLKPK Provinsi NTB)

\section{Analisis Data}

Data hasil analisis kandungan sianida diperoleh dalam satuan milligram/kilogram $(\mathrm{mg} / \mathrm{kg})$. data didapatkan dari hasil absorsi setiap sampel yang telah diukur menggunkan spektrofotometer. Adapun rumus yang digunakan untuk menentukan konsentrasi sianida dalam satuan $\mathrm{mg} / \mathrm{kg}$ yaitu sebagai berikut (Arisanti et al., 2018):

$$
\mathrm{CN}=\frac{(a-b)}{w} x V
$$

Keterangan:

$\mathrm{CN}=$ Kadar sianida pada sampel (ppm)

$\mathrm{a}=$ Nilai konsentrasi sampel hasil bacaan spektrofotometer (mg/L)

$\mathrm{b}=$ Nilai konsentrasi blanko hasil bacaan spektrofotometer $(\mathrm{mg} / \mathrm{L})$

$\mathrm{w}=$ Berat sampel $(\mathrm{Kg})$

$\mathrm{V}=$ Volume akhir larutan sampel (L)

Perbedaan struktur morfologi lamun dibuktikan dengan menggunakan SPSS uji Anova (one way anova) dengan pertimbangan Jika nilai sig. $>0,05$ maka rata-rata data adalah sama, sebaliknya jika nilai sig. $<0,05$ maka ratarata data adalah tidak sama (Sholeh, 2005).

\section{Hasil dan Pembahasan}

\section{Konsentrasi Kandungan Sianida}

Peran lamun sebagai bioindikator kandungan logam berat dalam perairan diantaranya adalah dengan cara mempengaruhi bioavaiabilitas logam berat pada sedimen. Berikut disajikan hasil analisis kandungan sianida di BLKPK Provinsi NTB periode bulan Juli - Agustus 2021.

Tabel 1. Hasil Analisis Sianida pada Lamun bulan Juli - Agustus 2021

\begin{tabular}{|l|l|l|l|l|l|}
\hline No & Stasiun & $\begin{array}{l}\text { Berat } \\
(\mathbf{K g})\end{array}$ & $\begin{array}{l}\text { Konsentrasi } \\
(\mathbf{m g} / \mathbf{L})\end{array}$ & $\begin{array}{l}\text { Standar baku } \\
(\mathbf{m g} / \mathbf{L})\end{array}$ & $\begin{array}{l}\text { Konsentrasi } \\
(\mathbf{m g} / \mathbf{k g})\end{array}$ \\
\hline 1 & 1 & 0,00231 & 0,302 & 0,5 & 7,55 \\
\hline 2 & 2 & 0,00201 & 0,411 & 0,5 & 10,275 \\
\hline 3 & 3 & 0,00210 & 0,768 & 0,5 & 19,2 \\
\hline & Rata-rata & & $\mathbf{0 , 4 9 5}$ & $\mathbf{0 , 5}$ & $\mathbf{1 2 , 3 4 1}$ \\
\hline
\end{tabular}

Tabel 1 menunjukan kadar sianida pada masing-masing lokasi penelitian. Standar baku kandungan sianida untuk wilayah perairan menurut Kementerian Kesehatan Republik
Indonesia No.57 tahun 2016 adalah 0,5 mg/L. Rata-rata konsentrasi sianida yang ditemukan sebesar $0,495 \mathrm{mg} / \mathrm{L}$. Hasil penelitian berbeda yang dilakukan oleh Astiti dan Sugianti (2014) 
dimana rata-rata lokasi deteksi kadar sianida pada tanah, air dan beras di Lombok Barat secara berturut-turut adalah $22,2 \%$; $66,7 \%$ dan $40,7 \%$ yang menunjukan bahwa lokasi pencemaran merkuri dan sianida oleh penambang emas sangat luas. Perbedaan nilai kandungan sianida yang ditemukan dapat disebabkan oleh perbedaan lokasi penelitian dan objek dalam penelitian.

\section{Parameter Lingkungan}

Parameter lingkungan dapat memberikan pengaruh terhadap kondisi lamun di wilayah perairan. Berikut disajikan data hasil pengukuran parameter lingkungan di perairan Pantai Pewaringan bulan Juli - Agustus 2021.

Tabel 2. Parameter Lingkungan

\begin{tabular}{|l|l|l|l|l|}
\hline No & Stasiun & $\mathrm{pH}$ & $\begin{array}{l}\text { Suhu } \\
\left({ }^{\circ} \mathrm{C}\right)\end{array}$ & $\begin{array}{l}\text { Salinitas } \\
(\mathrm{ppt})\end{array}$ \\
\hline 1 & 1 & 7 & 28 & 33,2 \\
\hline 2 & 2 & 7 & 28 & 32,0 \\
\hline 3 & 3 & 7 & 28 & 31,0 \\
\hline
\end{tabular}

Secara umum Perairan Pulau Lombok masih memiliki mutu air laut yang normal sesuai
Keputusan Menteri Lingkungan Hidup No. 51 Tahun 2004 Tentang Baku Mutu Air Laut yang ditunjukan pada tabel 3 .

Tabel 3. Standar Baku Mutu Air Keputusan Menteri Lingkungan Hidup No. 51 Tahun 2004

\begin{tabular}{|l|l|l|}
\hline No & $\begin{array}{l}\text { Parameter } \\
\text { lingkungan }\end{array}$ & Standar baku \\
\hline 1 & Suhu & $28-30{ }^{\circ} \mathrm{C}$ \\
\hline 2 & $\mathrm{pH}$ & $7-8,5$ \\
\hline 3 & Salinitas & $33-34$ \\
\hline
\end{tabular}

\section{Morfologi Tanaman Lamun}

Morfologi lamun merupakan penampakan lamun bagian luar meliputi bentuk, panjang, lebar, dan warna. Bagian Morfologi dapat digunakan sebagai bioindikator pencemaran logam berat yang berasal dari perairan dan sedimen (Ahmad et al., 2015). Berikut disajikan rata-rata hasil pengukuran daun, akar, dan batang lamun di Pantai Pewaringan bulan Juli - Agustus 2021.

Tabel 4. Rata-rata pengukuran daun, batang, dan akar lamun

\begin{tabular}{|c|c|c|c|c|c|c|c|c|}
\hline \multirow{2}{*}{ Stasiun } & \multicolumn{4}{|c|}{ Daun $(\mathrm{cm})$} & \multicolumn{2}{|c|}{ Batang $(\mathrm{cm})$} & \multicolumn{2}{|c|}{ Akar $(\mathrm{cm})$} \\
\hline & $\mathrm{P}$ & $\mathrm{L}$ & $\mathrm{W}$ & $\mathrm{J}$ & $\mathrm{P}$ & $\mathrm{D}$ & $\mathrm{P}$ & $\mathrm{D}$ \\
\hline 1 & 16 & 0,82 & $\mathrm{Ht}$ & 3 & 5,78 & 0,43 & 13,13 & 0,14 \\
\hline 2 & 18,3 & 1,18 & $\mathrm{Ht}$ & 4 & 8,63 & 0,8 & 5,54 & 0,27 \\
\hline 3 & 30,2 & 1,32 & $\mathrm{Hk}$ & 3 & 13,8 & 1,0 & 3,2 & 0,34 \\
\hline Rata-rata & 21,5 & 1,10 & - & 3 & 9,4 & 0,74 & 7,29 & 0,25 \\
\hline $\begin{array}{l}\text { Sig. } \\
\text { anova }\end{array}$ & 0,01 & 0,01 & - & - & 0,01 & 0,01 & 0,01 & 0,01 \\
\hline
\end{tabular}

\section{Pembahasan}

Berdasarkan laporan hasil uji BLKPK Provinsi NTB nilai kandungan sianida yang ditemukan di perairan Sekotong Lombok Barat berkisaran 7,55 - 19,2 $\mathrm{mg} / \mathrm{kg}$ dengan rata-rata sebesar 12, $341 \mathrm{mg} / \mathrm{kg}$. Penelitian Julistiana (2009) menyatakan kandungan sianida yang tidak berbahaya $<50 \mathrm{mg} / \mathrm{kg}$ dan berbahaya $>100 \mathrm{mg} / \mathrm{kg}$. Pritchard (2007) menyatakan dosis letal sianida berada pada kisaran $50-90 \mathrm{mg} / \mathrm{kg}$. Standar baku kandungan sianida untuk wilayah perairan menurut Kementerian Kesehatan Republik Indonesia No.57 tahun 2016 adalah 0,5 $\mathrm{mg} / \mathrm{L}$. Rata-rata konsentrasi sianida yang ditemukan di Pantai Pewaringan sebesar 0,495 $\mathrm{mg} / \mathrm{L}$ sehingga masih dalam batas aman sianida dalam perairan.

\section{Perbandingan Konsentrasi Sianida (CN)}

Kandungan sianida terendah ditemukan di stasiun 1 yaitu lokasi yang berdekatan dengan tempat parkir sampan nelayan $( \pm 150 \mathrm{~m})$ dengan kandungan $\mathrm{CN}$ sebesar 7,55 mg/kg. Rendahnaya kandungan sianida di lokasi ini dapat disebabkan karena tidak banyak dilewati oleh aktivitas manusia. Ukuran tubuh lamun juga dapat memberikan pengaruh terhadap kandungan $\mathrm{CN}$. Stasiun 1 memiliki ukuran daun, batang, dan akar lebih kecil daripada stasiun 2 dan 3. Rata-rata panjang dan lebar daun sebesar $16 \mathrm{~cm}$ dan 0,8 
$\mathrm{cm}$, panjang dan diameter batang sebesar $5,73 \mathrm{~cm}$ dan $0,43 \mathrm{~cm}$, serta panjang dan diameter akar rata-rata sebesar $13,13 \mathrm{~cm}$ dan $0,14 \mathrm{~cm}$. Hal ini berpengaruh terhadap kemampuan lamun dalam penyerapan $\mathrm{CN}$ yang rendah. Vigianti et al. (2017) mengatakan semakin bertambah umur tanaman maka penyerapan juga akan meningkat sampai pada waktu tertentu akan mencapai maksimum dan akan turun kembali. Pendapat yang sama oleh Supriyantini et al. (2016), menyatakan penyerapan kandungan logam berat dipengaruhi oleh umur lamun $T$. hemprichii semakin tua tumbuhan lamun maka kemampuan daun dalam menyerap logam berat juga akan meningkat.

Jenis substrat juga dapat berpengaruh terhadap pertumbuhan dan penyerapan $\mathrm{CN}$. Rahman et al. (2013) menyatakan perbedaan pertumbuhan daun lamun pada lokasi penelitian dapat disebabkan oleh faktor lingkungan seperti jenis substrat, salinitas, suhu, kecepatan arus dan gelombang di lokasi penelitian. Stasiun 1 memiliki ukuran daun, batang, dan akar lebih kecil daripada stasiun 2 dan 3. Hal ini dapat sebabkan oleh substrat tumbuh lamun yang berpasir sedikit berlumpur yang kurang cocok untuk lamun Thalasia hemprichi. Ramdhoni et al. (2018) menyatakan Jenis lamun Thalasia hemprichi di perairan Pulau Lombok didapatkan mendominasi yaitu di Pantai Poton bako, Pantai Pewaringan, dan Pantai Medana karena substrat yang mendukung yaitu substrat yang lumpur berpasir, dan berpasir yang memang cocok untuk habitat spesies Thalasia hemprichi. Substrat berlumpur memiliki ketersediaan unsur $\mathrm{N}$ (Nitrogen) dan P (Fosfor) yang lebih tinggi dibandingkan dengan lokasi yang berpasir (Erftemeijer, 1993 dalam Rahman et al. 2013).

Kandungan sianida pada stasiun 2 ditemukan sebesar 10, $275 \mathrm{mg} / \mathrm{kg}$. Stasiun 2 merupakan lokasi yang berada ditengah-tengah ekosistem padang lamun $( \pm 300 \mathrm{~m}$ dari pemukiman warga dan \pm 250 m dari tempat parkir sampan) dengan karakteristik lamun yang ditemukan diantaranya substrat berpasir sedikit berlumpur, warna daun hijau tua, nilai rata-rata panjang dan lebar daun sebesar $18,3 \mathrm{~cm}$ dan 1,18 $\mathrm{cm}$, panjang dan lebar batang sebesar $8,63 \mathrm{~cm}$ dan $0,8 \mathrm{~cm}$, serta panjang dan lebar akar rata-rata sebesar 5,54 cm dan $0,27 \mathrm{~cm}$. Tingginya kandungan $\mathrm{CN}$ pada di stasiun 2 daripada stasiun 1 dapat disebabkan oleh pertumbuhan lamun yang lebih tinggi di stasiun 2 daripada stasiun 1 , sehingga penyerapan $\mathrm{CN}$ lebih besar.
Kandungan sianida tertinggi ditemukan di stasiun 3 yaitu lokasi yang berdekatan dengan pemukiman warga $( \pm 200 \mathrm{~m})$ dengan nilai 19,2 $\mathrm{mg} / \mathrm{kg}$. Karakteristik lamun di stasiun 3 yaitu substrat berlumpur sedikit berpasir, warna daun hijau kekuningan, nilai rata-rata panjang dan lebar daun sebesar $30,2 \mathrm{~cm}$ dan $1,32 \mathrm{~cm}$, panjang dan lebar batang sebesar $13,8 \mathrm{~cm}$ dan $1,0 \mathrm{~cm}$, serta panjang dan lebar akar rata-rata sebesar 3,2 $\mathrm{cm}$ dan $0,34 \mathrm{~cm}$. Tingginya kandungan sianida pada stasiun 3 disebabkan karena lokasi tersebut berdekatan dengan pemukiman warga sehingga sianida tidak hanya berasal dari tanaman itu sendiri namun juga dari kendaraan bermotor, limbah industri dan limbah rumah tangga. Pertumbuhan lamun di stasiun 3 yang lebih tinggi daripada di stasiun 1 dan 2 juga dapat mempengaruhi penyerapan $\mathrm{CN}$. Tingginya pertumbuhan lamun di stasiun 3 dapat disebabkan oleh kondisi substrat yang sangat mendukung untuk tumbuh lamun Thalasia hemprichi. Sesuai hasil penelitian Erftemeijer, (1993) dalam Rahman et al. (2013) bahwa substrat berlumpur memiliki ketersediaan unsur $\mathrm{N}$ (Nitrogen) dan $\mathrm{P}$ (Fosfor) yang lebih tinggi. Selain itu umur lamun juga berpengaruh terhadap penyerapan CN. Vigianti et el. (2017) mengatakan semakin bertambah umur tanaman maka penyerapan juga akan meningkat sampai pada waktu tertentu akan mencapai maksimum dan akan turun kembali.

Tingginya penyerapan $\mathrm{CN}$ pada stasiun 3 memberikan dampak pada warna daun. Daun lamun di stasiun 3 berwarna hijau kekuningan daripada daun di stasiun 1 dan 2. Hal ini menunjukan lamun di stasiun 3 kurang sehat, karena lamun yang sehat ditandai dengan daun yang berwarna hijau sehingga memperlancar proses fotosintesis. Warna daun pada lamun dapat pengaruhi oleh tingkat penyerapan $\mathrm{CN}$, Sesuai penelitian Istiqomahani et al. (2020) Logam yang masuk keperairan dapat menyebabkan pengurangan kandungan kloroplas dalam daun. Kerusakan kloroplas akan menyebabkan terganggunya proses fotosintesis sehingga tanaman menjadi kemerahan atau kekuningan bahkan matinya sel-sel dalam jaringan.

Secara umum semua bagian morfologi lamun dapat digunakan sebagai bioindikator pencemaran logam berat yang berasal dari perairan dan sedimen (Ahmad et al., 2015). Pengukuran morfologi lamun menggunakan jenis Thalassia hemprichii karena spesies ini mendominasi pada lokasi penelitian. Ramdhoni 
et al. (2017) menyatakan Thalasia hemprichi merupakan jenis lamun yang paling tinggi mendominasi perairan Pulau Lombok dengan ditemukannya spesies ini pada semua lokasi penelitian. Pantai Pewaringan memiliki kondisi substrat yang lumpur berpasir, dan berpasir yang memang cocok untuk habitat spesies Thalasia hemprichi. Newmaster et al (2011) menjelaskan Thalassia hemprichii memiliki rimpang merayap, bercabang, dan rapuh, daun falcatus, tunas hitam kecoklatan, internodus pendek dan banyak.

\section{Sumber Pencemaran Sianida}

Kandungan sianida di alam dapat diproduksi oleh tumbuhan, tepatnya pada jaringan tumbuhan sebagai produk sampingan dari proses sintesis etilen, terutama pada saat ada jaringan tumbuhan yang terluka, perkecambahan, penuaan daun, dan pemasakan buah (Larsen, 2005 dalam Hidayati, 2008). Sianida secara alami dapat ditemukan dalam amygdalin (glukosida sianogenik) dengan konsentrasi rendah pada biji buah apel, ceri, almond, dan aprikot. Sedangkan sianida buatan dapat berasal dari inhalasi asap hasil kebakaran, bahan industri, aktivitas penambangan emas, dan perabotan rumah tangga (Cahyawati et al., 2017).

\section{Kualitas Perairan di Perairan Pantai Pewaringan}

Hasil pengukuran suhu di perairan Pantai Pewaringan di ketiga lokasi berkisaran rata-rata $28^{\circ} \mathrm{C}$ dan masih dalam kategori batas normal untuk lingkungan perairan. Kondisi ini dipengaruhi oleh lingkungan cuaca yang masih sejuk di lapangan, karena pengambilan sampel dilakukan pagi hari saat air laut masih surut dan matahari belum terbit. LIPI (2016) menyatakan kisaran suhu di pesisir Lombok Barat masih berada di batas baku mutu air laut menurut Keputusan Menteri Lingkungan Hidup No. 51 Tahun 2004 untuk biota laut yang hidup di ekosistem koral, mangrove, dan lamun, kecuali di Pelabuhan Lembar. Suhu perairan di pesisir Lombok Barat menunjukkan nilai yang hampir seragam, yaitu berkisar $29-30^{\circ} \mathrm{C}$.

Salinitas perairan di ketiga lokasi penelitian berkisaran 31-32 ppt dimana nilai ini masih dalam kisaran normal untuk kehidupan biota laut. Perbedaan nilai salinitas yang ditemukan pada lokasi penelitian tidak terlalu berbeda jauh dan masih dalam kisaran yang ditetapkan. LIPI (2016) menyatakan Kisaran salinitas di lokasi Teluk Sekotong, Pelabuhan
Lembar, Teluk Kombal, dan Gili Air masih baik untuk kehidupan organisme laut, khususnya ikan. Nilai salinitas yang rendah terjadi karena masuknya air dari sungai pada saat air laut surut. Baku mutu salinitas untuk kualitas air laut berdasarkan Kepmen LH No. 51 Tahun 2004 sebesar salinitas alami yang mampu mendukung kehidupan organisme, yaitu 33-34 ppt.

$\mathrm{PH}$ di perairan Pantai Pewaringan berkisaran 7 dan masih dalam kategori normal untuk kehidupan biota. Nilai $\mathrm{pH}$ yang ditemukan di lokasi penelitian cenderung homogen dan seragam. Hal ini disebabkan oleh $\mathrm{pH}$ air laut cenderung stabil dan tidak menunjukan perubahan yang signifikan di permukaan laut. Berdasarkan baku mutu PP No.82 Tahun 2001 $\mathrm{pH}$ perairan berkisar antara 6-9. Nilai $\mathrm{pH} \leq 6$ tergolong $\mathrm{pH}$ rendah yang mengindikasi perairan bersifat asam, sedangkan $\mathrm{pH} \geq 9$ tergolong $\mathrm{pH}$ tinggi yang mengindikasikan perairan bersifat basa. Kedua kondisi pH ini termasuk kategori tidak baik untuk kehidupan biota air. Perbedaan nilai $\mathrm{pH}$ di lokasi penelitian dipengaruhi oleh kondisi gas-gas seperti $\mathrm{CO}_{2}$, konsentrasi garam, serta limbah industri dan rumah tangga (Yulis, 2018).

\section{Kesimpulan}

Berdasarkan hasil penelitian Analisis Kandungan Sianida pada Tanaman Lamun sebagai Bioindikator di Perairan Sekotong Lombok Barat dapat disimpulkan sebagai berikut: 1). Morfologi akar, batang, dan daun lamun di perairan Pantai Pewaringan memiliki panjang daun rata-rata $21,5 \mathrm{~cm}$, lebar daun ratarata $1,10 \mathrm{~cm}$, panjang batang rata-rata $9,4 \mathrm{~cm}$, Diameter batang rata-rata $0,74 \mathrm{~cm}$, panjang akar rata-rata 7,29 serta diameter akar rata-rata 0,25 $\mathrm{cm}$. Uji anova menunjukan bahwa nilai signifikan $<0,05$, sehingga terdapat perbedaan yang signifikan pada morfologi tanaman lamun. 2). Kandungan sianida di perairan Pantai Pewaringan, ditemukan rata-rata sebesar 12,341 $\mathrm{mg} / \mathrm{kg}$ atau $0,495 \mathrm{mg} / \mathrm{L}$. Menurut Kementerian Kesehatan Republik Indonesia No.57 tahun 2016 kandungan sianida standar dalam perairan sebesar 0,5 mg/L. Sehingga Kandungan sianida di perairan Pantai Pewaringan masih dalam batas aman.

\section{Ucapan Terima Kasih}

Ucapan terima kasih saya ucapkan kepada Pihak BLKPK Provinsi NTB dan dosen FKIP Universitas Mataram. 


\section{Referensi}

Ahmad, F., Azman, S., Mohd Said, M. I., \& Baloo, L. (2015). Tropical seagrass as a bioindicator of metal accumulation. Sains malaysiana, 44(2).

Arisanti Dewi, Rasyid Nur Qadri, \& Nasir Muh. (2018). Analisis Kadar Sianida pada Rebung Berdasarkan Volume Ukuran dari Kecamatan Bajeng Kabupaten Gowa.

Astiti L.G.S \& Sugianti T. (2014). Dampak Penambangan Emas Tradisional pada Lingkungan dan Pakan Ternak di Pulau Lombok. Sains Peternakan, 12(2). 101106. ISSN 1693-8828.

Boneka, F.B. (2013). Pengantar Ekologi Laut. Unsrat Press. ISBN 987 - 979 - 3660 $11-0$.

Cahyawati Putu Nita, Zahran Izal, Jufri M. Ikhsan \& Noviana (2017). Keracunan Akut Sianida. Wicaksana Jurnal Lingkungan dan Pembangaunan:1(1)8087. ISSN 2597-7555

Christon OS., Djunaedi \& Purba NP. (2012). Pengaruh Tinggi Pasang Surut Terhadap Pertumbuhan dan Biomassa Daun Lamun Enhalus acoroides di Pulau Pari Kepulauan Seribu Jakarta. Jurnal Perikanan dan Kelautan, 3(3): 287-294.

Istiqomahani Dara Ramadhania, Suryono Chrisna Adhi, \& Pramesti Rini (2020). Korelasi Kandungan Logam Berat $\mathrm{Pb}$ dalam Air terhadap Daun Lamun Thalassia hemprichii (Ehrenberg) Ascherson 1871 (Magnoliopsida: Hydrocharitaceae) di Perairan Pulau Panjang dan Pantai Bandengan, Jepara. Journal of Marine Research, 9(2).

Newmaster AF., Berg KJ., Ragupathy S., Palanisamy M., Sambandan K \& Newmaster SG. (2011). Local Knowledge and Conservation of Seagrasses in The Tamil Nadu State of India. Journal of Ethnobiology and Ethnomedicine, 7:37.
Noviarini W \& Ermavitalini D. (2015). Analisa Kerusakan Jaringan Akar Lamun Thalassia hemprichii yang Terpapar Logam Berat Kadmium (Cd). Jurnal Sains dan Seni ITS, 4(2)

Republik Indonesia (2016). Peraturan Menteri Kesehatan Republik Indonesia Nomer 57 Tahun 2016 Tentang Rencana Aksi Nasional Pengendalian Dampak Kesehatan Akibat Pajanan Merkuri Tahun 2016-2020.

Ramdhoni Ahmad, Al-Idrus Agil, \& Santoso Didik (2017). Distribusi Lamun Di Pulau Lombok Nus Tenggara Barat Sebagai Bahan Praktikum Mata Kuliah Ekologi Pesisir Dan Laut. Skripsi S1 Universitas Mataram. Mataram.

Soleh Achmad Zanbar. (2005). Ilmu Statistika. Bandung: Rekayasa Sains Bandung.

Susila I Putu Mogi, Muhlis, \& Bahtiar Imam (2018). Komunitas Echinodermata pada Padang Lamun Pantai Pewaringan dan Pantai Lenggolong di Sekotong Lombok Barat. Skripsi S1 Universitas Mataram. Mataram

Supriyantini, E., Sri, S. \& Zidny, N. (2016). Akumulasi Logam Berat Zn (seng) pada Lamun Enhalus acoroides dan Thalassia hemprichii di perairan Pantai Kartini Jepara. Buletin Oseanografi Marina. 5(1):14-20. doi: 10.14710/buloma.v5i1.1129

Syukur A. (2015). Distribusi, Keragaman Jenis Lamun (Seagrass) dan Status Konservasinya di Pulau Lombok. Jurnal Biologi Tropis. 15 (2): 163-176.

Syukur A, Wardiatno Yusli, Muchsin Ismudi \& Kamal, Mohammad Mukhlis (2017). Kerusakan Lamun (seagrass) dan Rumusan Konservasinya di Tanjung Luar Lombok Timur. Jurnal Biologi Tropis, 17 (2). p-ISSN: 1411-9587 e-ISSN:25497863

Vigiyanti, Kiki A., L. Chamisijatin, Rr. E. \& Susetyarini (2017). Pengaruh Umur Tanaman Perairan Teluk Jakarta. Jurnal Geologi Kelautan. 11(1):9-16. 
Vigiyanti, K. A., Lise, C., \& Eko, R.S. (2017). Pengaruh Umur Tanaman Terhadap Penyerapan Logam $\mathrm{Pb}$ Pada Azolla microphylla Dimanfaatkan Sebagai Sumber Belajar Biologi. Prosiding Seminar Nasional III Tahun 2017 Biologi, Pembelajaran, dan Lingkungan Hidup Perspektif Interdisipliner, Malang, 29 April 2017.

Zamani, N.P., Prartono, T., Arman, A., Ariesta, D.S. \& Wahab, I., (2018). The concentration of Heavy Metals on Roots, Stem, and Leaves of Enhalus Acoroides, in Tundra Island, Banten Bay.Jurnal Ilmu dan Teknologi Kelautan Tropis, 10(3) 